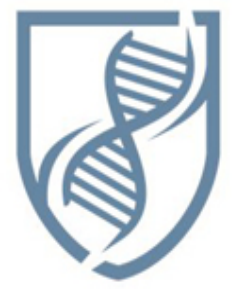

Journal of Bioscience and Applied Research
JBAAR

WWW.JBAAR.ORG

\title{
fertility in induced azoospermic mice
}

\author{
El-Fiky, B.A. \\ (Corresponding authors e-mail bahgat_elfeky@yahoo.com)
}

Animal Biotechnology Department, Genetic Engineering and Biotechnology Institute, University of Sadat City, Egypt

\begin{abstract}
:
Impairment of spermatogenesis has been shown in patients treated with chemotherapy against different malignancies resulting in azoospermia. The present study was designed to assess the ability of anti-SCa-1and CD105 mesenchymal stem cells to restore fertility in induced azoospermic mice following cyclophosphamide administration. Forty male mice were divided randomly into four groups, each group included 10 male albino mice which has an average body weight 22-25 g; group (1): normal control, group (2): male azoospermic mice induced with cyclophosphamide, group (3): male azoospermic mice received anti-SCa-1+ stem cells into caudal vein, group (4): male azoospermic mice received CD 105 MSCs into caudal vein. Androgen hormonal profile and histological assessment of testicular tissues were evaluated pre- and post-treatment with anti-Sca- $1^{+}$and mesenchymal stem cell transplantation. Results showed that male azoospermic mice treated with anti-SCa- $1+$ and CD105 MSCs stem cells after 12 weeks of treatment are able to improve androgen hormonal profile levels and resuming spermatogenesis as verified by histological assessment of testicular tissues and hormonal profile as compared to control groups. Also data obtained from the study showed no significant differences between anti-SCa-1+ and CD105 MSCs treated groups. In conclusion, both of anti-SCa-1 and CD105 MSCs have the potentiality to differentiate into germ cells and sperms in vivo in testicular microenvironment, and also able to restore testicular functions.
\end{abstract}

KeyWords: male mice, cyclophosphamide, azoospermia, anti-SCa-1+ and CD105 MSCs.

\section{Introduction}

Stem cells are body's unspecialized cells that has the ability to self-renew and differentiate into various cell types depending on the stimuli that they received. Stem cells are classified into embryonic stem cells (ESC) and adult stem cells (ASC), whereas ESC are derived from inner cell mass of blastocyst, ASC usually originate from various tissues of developed individual (Phinney and Prockop, 2007).

The differentiation potentiality of stem cell is classified into totipotent, pluripotent and multipotent. A fertile egg is totipotent and can differentiate into any cell type. The embryonic stem cell is pluripotent and can differentiate into any cell type except a fertilized egg. The adult stem cell is multipotent and can differentiate into most cell types of its tissue origin (Kolf et al., 2007). The capacity of stem cells to differentiate into almost all of the cell types of human body highlight potentially promising role in cell replacement therapies for the treating of human diseases (Stojkovic et al., 2004).

Infertility is one of the commonest problems that affects $13-18 \%$ of couples with increasing incidence of male reproductive problems. There is a male factor involves up to $50 \%$ of all infertile couples (Geijsen et al., 2004). The infertile male presented with abnormal sperm production such as oligospermia in about $11 \%$, asthenospermia in about $13 \%$, teratospermia in about $10 \%$ or azoospermia in about $21 \%$ of the cases. The treatment for male infertility is limited and most often arrange of in vitro fertilization (IVF) technique or intracytoplasmic sperm injection (ICSI) which are used circumvent rather than treatment (Bukovsky et al., 2004).

Stem cells can provide a true therapy for these problems, Toyooka et al. (2003) showed that ESC could form male germ cells in vitro; the induced germ cells could participate in spermatogenesis when transplanted into reconstituted testicular tubules demonstrating that ESC can produce functional germ cells in vitro. Geijsen et al. (2004) revealed that ESC derived embryoid bodies supported maturation of primordial germ cells into haploid main gametes, when injected into oocyte restored the somatic 
diploid chromosome complement and developed into blastocysts. Nayernia et al. (2004) reported that the in vitro generation of germ cell line from pluripotent teratocarcinoma cells forms mature seminiferous tubule structures and supported spermatogenesis after transplantation into recipient testis. Finally, for the first time, ESC-derived germ cells are able to generate offspring mice (Nayernia et al., 2006). These findings rise the using of stem cells to treat male infertility and testosterone deficiency (Satija et al., 2007). Certainly application of stem cells for therapeutic purpose still premature, however, the results achieved in stem cell researches demonstrate rapid progress in the importance of stem cells in the basic research and the long term future of modern medicine (Abeyta et al., 2004).Therefore, the present study designed to evaluate stem cells ability to differentiate into spermatogenic-like cells in azoopermic mice experimentally induced by cyclophosphamide.

\section{Materials and Methods}

This study was a prospective clinical experimental observational animal study done in Stem Cell lab at Genetic Engineering and Biotechnology Research Institute, University of Sadat City during the period from January December 2015. Ethical committee approval was taken from the ethical committee in Genetic Engineering \& Biochemical Research Institute, University of Sadat City.

\subsection{Experimental animal model:}

Forty mature male Swiss albino mice with an average age 6-8 weeks with an average weight between 2225 g were purchased from National Research Center, Cairo, Egypt. Mice were housed at the animal house of Genetic Engineering and Biotechnology Research Institute (GEBRI), University of Sadat City in steel cages (5 mice/cage) and maintained for two weeks acclimatization period on commercial standard diet and tap water ad libitum in an air-conditioned animal house with controlled temperature $\left(28^{\circ} \mathrm{C}-30^{\circ} \mathrm{C}\right)$ and specific pathogen free conditions, and subjected to a 12:12h daylight/ darkness.

\subsection{Induction of azoospermia in mice.}

Azoospermia was induced in 30 albino mice by intraperitoneal injection of a loading dose of cyclophophamide (150 mg/kg), followed by daily cyclophosphamide injection at $8 \mathrm{mg} / \mathrm{kg}$ for 7 consecutive days. Confirmation of testicular failure was done by measuring $\mathrm{FSH}, \mathrm{LH}$ and testosterone hormonal levels, and the histopathology of testes.

\subsection{Experimental design:}

Forty male mice were divided randomly into four groups, each group included 10 male albino mice with an average body weight 22-25 g.; group (1): normal control mice, group (2): male azoospermic mice induced with cyclophosphamide, group (3): male azoospermic mice induced with cyclophosphamide and received antiSCa- $1^{+}$ stem cells and group (4): male azoospermic mice induced with cyclophosphamide and received CD105 MSCs into caudal vein. After the last injection of cyclophosphamide. $3 \times 10^{7}$ AntiSCa- $1^{+}$stem cells suspended in a $20-\mu \mathrm{L}$ phosphate buffer saline were injected in the caudal vein of the mice of group (3), $3 \times 10^{7}$ MSCs stem cells suspended in a $20-\mu \mathrm{L}$ phosphate buffer saline were injected in the caudal vein of the mice of group (4). After transplantation, blood samples were collected from all mice groups and serum was separated and stored at $-80^{\circ} \mathrm{C}$ for hormonal estimation.

\subsection{Hormonal assessment:}

Hormonal assessment was done for all mice included in the study in the four groups as a base line and during the follow up period. Testosterone, L.H and FSH levels were measured using the ELISA kit (BioCheck, Inc., USA catalog No: BC-1115, BC-1111 BC-1113 respectively) according to the manufacturer's instructions.

\subsection{Histological evaluation of spermatogenesis:}

The animals were sacrificed and their testes were removed, washed in $0.9 \%$ saline solution and fixed in $10 \%$ neutral buffer formalin. The fixed samples were then embedded in paraffin and sectioned ( $5 \mu \mathrm{m}$ thick) on gelatin pre-coated slides. They were further deparaffinized, stained with Hematoxylin-Eosin and observed under a light microscope (Carl Zeiss).

\subsection{Mononuclear cells separation}

Bone marrow samples were collected from femur and tibias by flushing the shaft with phosphate buffer saline using a syringe with $26 \mathrm{G}$ needle. Bone marrow blood was diluted with running buffer to 3:1, and $9 \mathrm{ml}$ of diluted blood cells suspension was carefully layered over $3 \mathrm{ml}$ Ficoll Hypaque (1.077 density) in a $15 \mathrm{ml}$ conical tube and centrifuged at $1000 \mathrm{rpm}$ for 30 minutes at $+4^{\circ} \mathrm{C}$ in a swinging-bucket rotor without brake. The upper layer was aspirated off leaving the mononuclear cell layer undisturbed at the interphase, and then the interphase cells (lymphocytes and monocytes) were carefully transferred to a new $15 \mathrm{ml}$ conical tube and filled with PBS containing 2 mM EDTA.

Cells were mixed well and centrifuged at $1000 \mathrm{rpm}$ for 10 minutes at $+4^{\circ} \mathrm{C}$ then the supernatant was carefully removed completely. The pellet was resuspended in $15 \mathrm{ml}$ PBS containing $2 \mathrm{mM}$ EDTA and centrifuged at $1000 \mathrm{rpm}$ for 10 minutes at $+4^{\circ} \mathrm{C}$, then the supernatant was carefully removed completely.

Viability test of mononuclear cells was carried out by mixing one drop of cell suspension with one drop of $0.4 \%$ trypan blue vital stain in separate eppendorf tube and cell counting was done using haemocytometer. The pellet was resuspended in a final volume of $300 \mu \mathrm{l} / 108$ total cells, and then magnetic labeling was proceeded.

\subsection{Magnetic labeling of AntiSCa-1+and separation with auto MACS separator}

Cells were disaggregated by gently pipetting several times, and then passed through $30 \mu$ nylon mesh (PreSeparation Filters\# 130-041-407) to remove cell clumps. Cell pellet was resuspended in $90 \mu \mathrm{L}$ running buffer (MACS separation buffer containing $0.5 \%$ bovine serum albumin, phosphate buffered saline, $\mathrm{pH} 7.2$, and $2 \mathrm{mM}$ EDTA and $0.09 \%$ sodium azide). $10 \mu$ of Direct Anti-Sca1'Progenitor Cell Isolation kit was added to cell suspension and mix well then incubated for 30 minutes in the refrigerator at $+4^{\circ} \mathrm{C}$ ), washed by adding $1-2 \mathrm{~mL}$ of buffer 
and centrifuged again in $+4^{\circ} \mathrm{C}$ cooling centrifuge at 1000 rpm for 10 minutes. Column was placed in the magnetic field of MACS Separator. Cell suspension was then applied on to the column. AntiSCa-1+ cells were attached to the column while. After complete separation, the separation column was separated from the column and AntiSCa- $1^{+}$was eluted by the use of running buffer to undergo proliferation in vitro.

\subsection{Magnetic labeling of $\mathrm{CD}^{105+}$ and separation with auto MACS separator}

\subsection{Magnetic labeling of $\mathrm{CD}_{105+\text { and }}$ separation with auto} MACS separator

The negative selection of antiSca- $1^{+}$cells was resuspended in $90 \mu \mathrm{L}$ running buffer, and $10 \mu \mathrm{l}$ of CD105 Progenitor Cell Isolation Kit was added to the cell suspension and mix well, then incubated for 30 minutes in the refrigerator at $+4^{\circ} \mathrm{C}$ ), washed by adding $1-2 \mathrm{~mL}$ of buffer and centrifuged again in $+4^{\circ} \mathrm{C}$ cooling centrifuge at $1000 \mathrm{rpm}$ for 10 minutes. Magnetic separation column was placed in the magnetic field of MACS Separator. Cell suspension was then applied on to the column, where CD105+cells were attached to the column and non attached cells were eluted. After complete separation, the separation column was separated from the column and CD105+ was eluted by using running buffer to undergo proliferation in vitro.

\subsection{AntiSCa-1+ and CD105+Mesenchymal stem cells proliferation}

Both of AntiSCa- $1^{+}$and CD105+ mesenchymal stem cells were seeded in $75 \mathrm{~cm}^{3}$ cell culture flask with vented cap (Nunc AIS, Roskilde, Denmark) at cell density $3 \times 10^{6}$ / $\mathrm{ml}$ in DMEM growth medium ((Sigma, St Louis, Mo, USA): supplemented with $2.4 \mathrm{~g}$ sodium bicarbonate/lit. 10\% Fetal Bovine Serum (Sigma, St Louis, Mo, USA): inactivated at $56^{\circ} \mathrm{G}$ water bath for $30 \mathrm{~min}$ before use.) and incubated at $37^{\circ} \mathrm{C}$ in $5 \% \mathrm{CO} 2$ incubator and $95 \%$ humidity for three days. The non-adherent cell in CD105+ mesenchymal stem cells cell fraction were aspirated off, and the adherent cells which had fibroblast like appearance were left to complete their growth to reach confluence. AntiSCa-1+ hematopoietic stem cells recognized by their colony formation. The proliferation proceeded for two weeks at which growth medium changed every 3 days.

\subsection{Statistical analysis:}

Data was analyzed by using SPSS 11.0 for Windows. The significance of differences calculated using one - way analysis of variance (ANOVA) followed by Turkey's procedure for multiple comparisons according to Montogomery (1997). $P<0.05$ was considered statistically significant.

\section{Results}

3.1 Stem cells proliferation: MSCs attached to the culture flasks sparsely and displayed a fibroblast-like, spindleshaped morphology during the initial days of incubation. Following 3-4 days of incubation, proliferation started and the cells gradually grew into small colonies. During culture, adjacent colonies interconnected with each other and a monolayer confluence was obtained after $12-15$ days of incubation. In later passages, MSCs exhibited large, flattened fibroblast-like morphology and did not change throughout cell passages. The effect of seeding density was reflected also in cell morphology changing from thin spindle-like shape in low densities into flattened appearance in dense cultures (Fig. 1a-b). Rounded spherical cells forming colonies were seen in antiSca $1^{+}$cell culture (1.C). The viability of cells was higher than $95 \%$, determined by trypan blue staining of cells before transplantation.

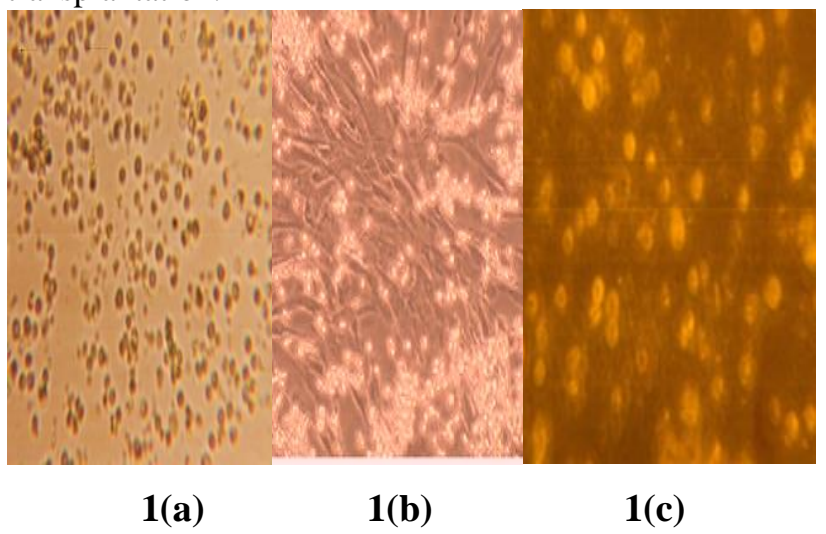

Fig. (1): Morphological and phenotypic characteristics of mice BM-MSCs and AntiSCa- $1^{+}$stem cells. During the onset of culture P0-3th day, some of the isolated cells are still spherical in shape (a), while others begin to form fibroblast shape shape like cells characteristic to MSCs or colonies formation characteristic to antiSCA $1^{+}$(c). Prominent alterations in morphology were documented after 1 week of culture after the next days and passages, most of these MSCs exhibited large, flattened or fibroblastlike morphology (b). The antiSca 1 cells has rounded colony cells formation(C) ( X:40).

\subsection{Histological Assessment of Spermatogenesis:}

Azoospermic mice treated group showed that most of the seminiferous tubules has a thick wall with a very limited lumen. The wall consists of several layers of seminiferous epithelial cells, with the spermatogonia in the outer layer, the spermatocytes in the middle and the spermatozoa and spermatids protruding toward the lumen, which represent a fully spermatogenic seminiferous tubule. After induction of azoospermic mice, testes were thoroughly analyzed for any spontaneous recovery of spermatogenesis, where no signs were observed for reinitiated spermatogenesis. The scanning of cross sections of these tubules showed reduced diameters with small lumens and few spermatogonia. Nuclei of Sertoli cells had become smaller (Figs 2-4). 


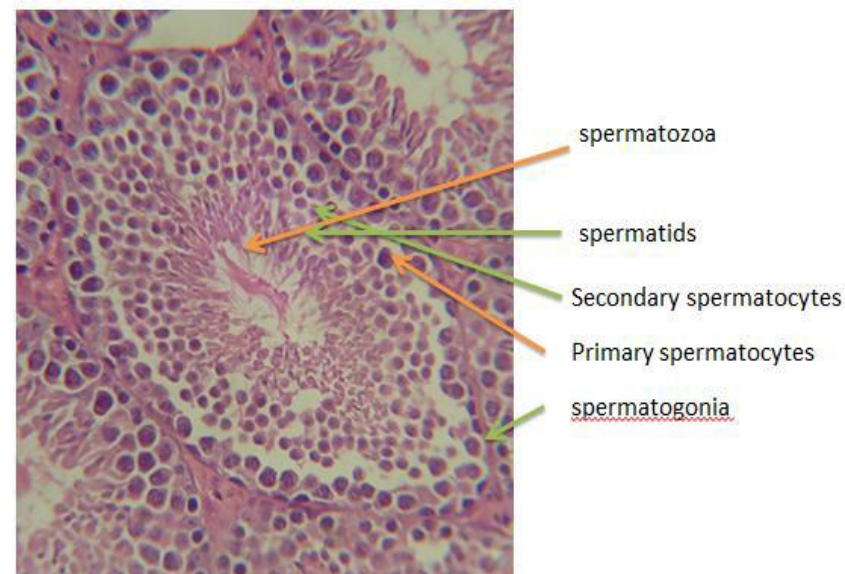

Fig. (2): Photomicrographs of cross-sections from normal male mice testes showing a typical fully normal appearing spermatogenesis organization in seminiferous tubules. (X:100)

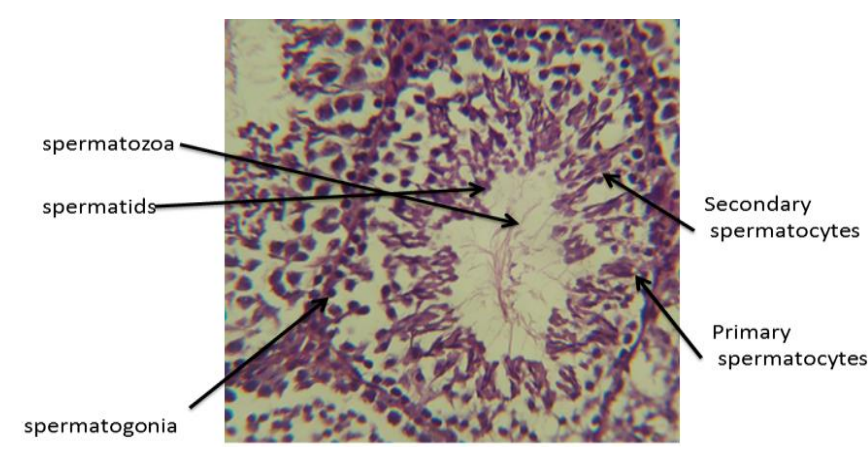

Fig. (3): Photomicrographs of cross-sections from male mice azoospermic testes showing seminiferous tubules with a typical non spermatogenesis, the population of spermatogonia was markedly decreased, and many tubules contained only Sertoli cells (arrows) ( X:100).

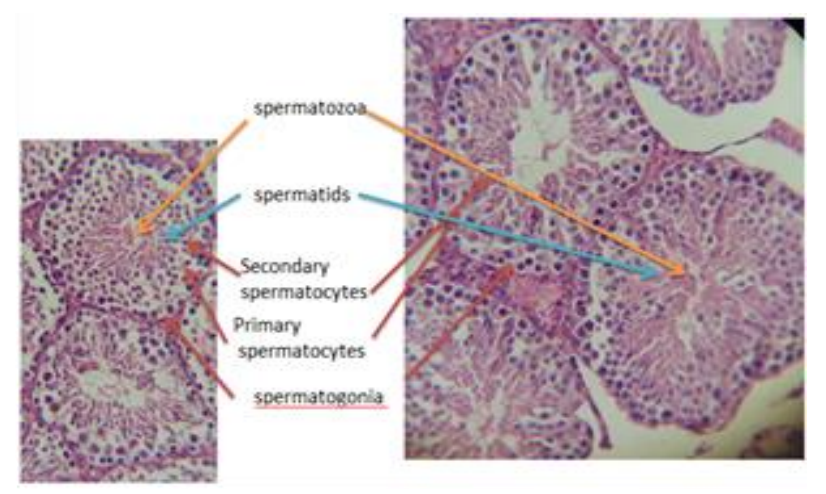

Fig. (4): Photomicrographs of cross-sections from male mice azoospermic testes treated with anti SCa- $1^{+}$ hematopoietic stem cells (4a) and CD105 MSCs (4b) showed restoration of spermatogenesis . (X100).

\subsection{Hormonal assessment of spermatogenesis:}

Serum hormonal assay showed a decrease in testosterone level compared to the normal control group, despite the increase in serum testosterone level in cyclophosphamide group there was no any significant difference among other groups, regeneration of spermatogenesis was not observed. Also hormonal assessment demonstrated that FSH showed significant decrease in cyclophosphamid group than those of the other groups $(\mathrm{P}<0.05)$. On the other hand LH was increased in serum levels compared to the control group, but no statistically significant difference was detected between the LH in cyclophosphamide, MSCs and the control group. These observations indicated that the effects of LH and FSH on spermatogenesis were synergistic (Tab. 14). Data presented in the table shows that there was a highly significant difference between control group and study group regarding FSH, testosterone and LH hormones.

Data presented in table (2) show no significant difference between control group and study group regarding testosterone levels in $\mathrm{ng} / \mathrm{mL}, \mathrm{FSH} \mathrm{mIU} / \mathrm{ml}$ and $\mathrm{LH} \mathrm{mIU} / \mathrm{ml}$ before induction. There was highly significant difference between control group and (group: 2, group: 3 , group: 4) $\mathrm{P}<0.01$ in all hormonal study, no significant difference was recorded between group: 3 and group: 4 in all study hormones (table 3).

Data presented in Table (4) show highly significant difference between control group and group: $2(\mathrm{P}<0.01)$ in all hormonal study, no significant difference between control group and (group: 3, group: 4) $\mathrm{P}>0.05$ in all hormonal study, highly significant difference between group 2 and (group: 3, group: 4) $\mathrm{P}<0.01$ in all study hormones and no significant difference between group: 3 and group: 4 ( $\mathrm{P}>0.05)$ in all study hormones. 
Table (1): Comparison between studied groups over the period of study regarding Testosterone, FSH and LH hormone.

\begin{tabular}{||c||c||c|c|c|c|c||}
\hline & $\begin{array}{c}\text { Group: 1 } \\
\text { Mean } \pm \text { S.D }\end{array}$ & $\begin{array}{c}\text { Group: 2 } \\
\text { Mean } \pm \text { S.D }\end{array}$ & $\begin{array}{c}\text { Group: 3 } \\
\text { Mean } \pm \text { S.D }\end{array}$ & $\begin{array}{c}\text { Group: 4 } \\
\text { Mean } \pm \text { S.D }\end{array}$ & F.test & P.value \\
\hline \hline FSH before & $0.47 \pm 0.02$ & $0.49 \pm 0.05$ & $0.46 \pm 0.02$ & $0.47 \pm 0.02$ & 1.736 & .177 \\
\hline \hline FSH.2 weeks & $0.38 \pm 0.04$ & $2.23 \pm 0.13$ & $3.27 \pm 1.02$ & $3.30 \pm 1.03$ & 5.264 & .000 \\
\hline \hline FSH.4 weeks & $0.42 \pm 0.02$ & $3.70 \pm 0.19$ & $2.24 \pm 0.10$ & $2.29 \pm 0.12$ & 16.760 & .000 \\
\hline FSH.8 weeks & $0.43 \pm 0.01$ & $5.35 \pm 0.14$ & $1.65 \pm 0.20$ & $1.68 \pm 0.21$ & 31.219 & .000 \\
\hline \hline FSH.10 weeks & $0.47 \pm 0.02$ & $8.15 \pm 0.19$ & $0.79 \pm 0.11$ & $0.80 \pm 0.10$ & 32.835 & .000 \\
\hline \hline FSH.12weeks & $0.47 \pm 0.02$ & $9.19 \pm 0.20$ & $0.48 \pm 0.10$ & $0.49 \pm 0.10$ & 29.368 & .000 \\
\hline Testosterone before & $0.47 \pm 0.02$ & $0.33 \pm 0.31$ & $0.41 \pm 0.03$ & $0.42 \pm 0.03$ & 27.362 & .000 \\
\hline \hline Testosterone 2 weeks & $0.49 \pm 0.04$ & $0.52 \pm 0.04$ & $0.53 \pm 0.04$ & $0.54 \pm 0.04$ & 4.495 & .06 \\
\hline \hline Testosterone 4 weeks & $0.50 \pm 0.03$ & $0.38 \pm 0.05$ & $0.25 \pm 0.02$ & $0.26 \pm 0.03$ & 89.575 & .000 \\
\hline Testosterone 6 weeks & $0.49 \pm 0.04$ & $0.16 \pm 0.04$ & $0.41 \pm 0.01$ & $0.41 \pm 0.02$ & 50.851 & .000 \\
\hline \hline Testosterone 8 weeks & $0.50 \pm 0.03$ & $0.10 \pm 0.023$ & $0.44 \pm 0.022$ & $0.44 \pm 0.02$ & 56.756 & .000 \\
\hline Testosterone10 weeks & $0.49 \pm 0.04$ & $0.06 \pm 0.02$ & $0.49 \pm 0.04$ & $0.49 \pm 0.04$ & 43.372 & .000 \\
\hline \hline LH before & $0.51 \pm 0.01$ & $0.51 \pm 0.01$ & $0.51 \pm 0.01$ & $0.51 \pm 0.01$ & 0.126 & .944 \\
\hline \hline LH.2 weeks & $0.51 \pm 0.01$ & $0.58 \pm 0.04$ & $0.80 \pm 0.03$ & $0.77 \pm 0.06$ & 17.707 & .000 \\
\hline LH.4weeks & $0.51 \pm 0.01$ & $0.68 \pm 0.03$ & $0.79 \pm 0.03$ & $0.76 \pm 0.05$ & 37.861 & .000 \\
\hline \hline LH.6weeks & $0.51 \pm 0.01$ & $0.70 \pm 0.04$ & $0.70 \pm 0.02$ & $0.69 \pm 0.03$ & 32.890 & 000 \\
\hline \hline LH.8weeks & $0.52 \pm 0.02$ & $0.72 \pm 0.06$ & $0.67 \pm 0.05$ & $0.65 \pm 0.06$ & 31.316 & .000 \\
\hline \hline LH.10weeks & $0.51 \pm 0.01$ & $0.76 \pm 0.07$ & $0.65 \pm 0.04$ & $0.64 \pm 0.05$ & 43.349 & .000 \\
\hline LH.12weeks & $0.51 \pm 0.01$ & $0.83 \pm 0.10$ & $0.54 \pm 0.02$ & $0.54 \pm 0.02$ & 80.490 & .000 \\
\hline \hline
\end{tabular}

Table (2): Comparison between the mean Testosterone levels, FSH and LH between testicular failure induced group by CTX (group: 2), received anti-sca1 ${ }^{+}$cells (group: 3) and MSC after Testicular failure (group:4) before induction.

\begin{tabular}{|c|c|c|c|c|c|}
\hline & $\begin{array}{c}\text { Group: } 1 \\
\text { Mean } \pm \text { S.D }\end{array}$ & $\begin{array}{c}\text { Group: } 2 \\
\text { Mean } \pm \text { S.D }\end{array}$ & $\begin{array}{c}\text { Group: } 3 \\
\text { Mean } \pm \text { S.D }\end{array}$ & $\begin{array}{c}\text { Group: } 4 \\
\text { Mean } \pm \text { S.D }\end{array}$ & P.value \\
\hline $\begin{array}{c}\text { FSH } \\
\mathrm{mIU} / \mathrm{ml}\end{array}$ & $0.47 \pm 0.02$ & $0.49 \pm 0.05$ & $0.46 \pm 0.02$ & $0.47 \pm 0.02$ & $\begin{array}{l}\mathrm{P} 1>0.05 \\
\mathrm{P} 2>0.05 \\
\mathrm{P} 3>0.05 \\
\mathrm{P} 4>0.05\end{array}$ \\
\hline $\begin{array}{c}\text { Testosterone } \\
\text { ng/mL }\end{array}$ & $0.51 \pm 0.03$ & $0.52 \pm 0.04$ & $0.53 \pm 0.04$ & $0.54 \pm 0.04$ & $\begin{array}{l}\mathrm{P} 1>0.05 \\
\mathrm{P} 2>0.05 \\
\mathrm{P} 3>0.05 \\
\mathrm{P} 4>0.05\end{array}$ \\
\hline $\begin{array}{c}\mathrm{LH} \\
\mathrm{mIU} / \mathrm{ml}\end{array}$ & $0.51 \pm 0.01$ & $0.51 \pm 0.01$ & $0.51 \pm 0.01$ & $0.51 \pm 0.01$ & $\begin{array}{l}\mathrm{P} 1>0.05 \\
\mathrm{P} 2>0.05 \\
\mathrm{P} 3>0.05 \\
\mathrm{P} 4>0.05\end{array}$ \\
\hline
\end{tabular}


Table (3): Comparison between the mean Testosterone levels, FSH and LH mIU/ml between testicular failure induced group by CTX (group: 2), received anti-sca1 cells (group: 3) and MSCs after Testicular failure (group:4) after induction during the study.

\begin{tabular}{|c|c|c|c|c|c|}
\hline & $\begin{array}{c}\text { Group: } 1 \\
\text { Mean } \pm \text { S.D }\end{array}$ & $\begin{array}{c}\text { Group: } 2 \\
\text { Mean } \pm \text { S.D }\end{array}$ & $\begin{array}{c}\text { Group: } 3 \\
\text { Mean } \pm \text { S.D }\end{array}$ & $\begin{array}{c}\text { Group: } 4 \\
\text { Mean } \pm \text { S.D }\end{array}$ & P.value \\
\hline $\begin{array}{c}\text { FSH } \\
\mathrm{mIU} / \mathrm{ml}\end{array}$ & $0.47 \pm 0.02$ & $0.33 \pm 0.31$ & $0.41 \pm 0.03$ & $0.42 \pm 0.03$ & $\begin{array}{l}\mathrm{P} 1<0.01 \\
\mathrm{P} 2>0.05 \\
\mathrm{P} 3>0.05 \\
\mathrm{P} 4<0.01\end{array}$ \\
\hline $\begin{array}{l}\text { Testosterone } \\
\text { ng/mL }\end{array}$ & $0.49 \pm 0.04$ & $0.03 \pm 0.022$ & $0.52 \pm 0.023$ & $0.53 \pm 0.02$ & $\begin{array}{l}\mathrm{P} 1<0.01 \\
\mathrm{P} 2>0.05 \\
\mathrm{P} 3>0.05 \\
\mathrm{P} 4<0.01\end{array}$ \\
\hline $\begin{array}{c}\mathbf{L H} \\
\mathrm{mIU} / \mathrm{ml}\end{array}$ & $0.51 \pm 0.01$ & $0.83 \pm 0.10$ & $0.54 \pm 0.02$ & $0.54 \pm 0.02$ & $\begin{array}{l}\mathrm{P} 1<0.01 \\
\mathrm{P} 2>0.05 \\
\mathrm{P} 3>0.05 \\
\mathrm{P} 4<0.01\end{array}$ \\
\hline
\end{tabular}

Table (4): Comparing the mean Testosterone levels, FSH and LH between testicular failure induced group by CTX (group: 2), received anti-sca1 cells (group: 3) and MSC after Testicular failure (group: 4) at the end of the study.

\begin{tabular}{|c|c|c|c|c|c|}
\hline & $\begin{array}{c}\text { Group: } 1 \\
\text { Mean } \pm \text { S.D }\end{array}$ & $\begin{array}{c}\text { Group: } 2 \\
\text { Mean } \pm \text { S.D }\end{array}$ & $\begin{array}{c}\text { Group: } 3 \\
\text { Mean } \pm \text { S.D }\end{array}$ & $\begin{array}{c}\text { Group: } 4 \\
\text { Mean } \pm \text { S.D }\end{array}$ & P.value \\
\hline $\begin{array}{c}\text { FSH } \\
\mathrm{mIU} / \mathrm{ml}\end{array}$ & $0.38 \pm 0.04$ & $2.23 \pm 0.13$ & $3.27 \pm 1.02$ & $3.30 \pm 1.03$ & $\begin{array}{l}\mathrm{P} 1<0.01 \\
\mathrm{P} 2<0.01 \\
\mathrm{P} 3<0.01 \\
\mathrm{P} 4<0.01\end{array}$ \\
\hline $\begin{array}{l}\text { Testosterone } \\
\mathrm{ng} / \mathrm{ml}\end{array}$ & $0.49 \pm 0.04$ & $0.26 \pm 0.03$ & $0.25 \pm 0.02$ & $0.26 \pm 0.03$ & $\begin{array}{l}\text { P1 }<0.01 \\
\text { P2 }<0.01 \\
\text { P3 }<0.01 \\
\text { P4 }<0.01\end{array}$ \\
\hline $\begin{array}{c}\mathbf{L H} \\
\mathrm{mIU} / \mathrm{ml}\end{array}$ & $0.51 \pm 0.01$ & $0.58 \pm 0.04$ & $0.80 \pm 0.03$ & $0.77 \pm 0.06$ & $\begin{array}{l}\mathrm{P} 1<0.01 \\
\mathrm{P} 2<0.01 \\
\mathrm{P} 3<0.01 \\
\mathrm{P} 4<0.01\end{array}$ \\
\hline
\end{tabular}




\section{4- Discussion}

The present study was carried out to assess the regenerative capacity of mice bone marrow derived antiSca- $1^{+}$and mesenchymal stem cells transplanted into the induced azoospermic mice testes after 12 weeks of follow up. Data of the presented study showed that stem cells were able to recover testicular functions. Testis represents a unique microenvironment for donor stem cell migration, proliferation, differentiation and apoptosis. The testis is protected from immunological influences by the blood testis barrier allowing the recipient to host donor cells without rejection (Lue, 2007).

Histological examination showed that more than $95 \%$ of the seminiferous tubules had become nonspermatogenic, with the depletion of about $95 \%$ of the haploid cells (the spermatids and spermatozoa) after 12 weeks in mice treated with $150 \mu / \mathrm{kg}$ cyclophosphamide. These results are in agree with that published by (Ogawa, 1999) who revealed that the system of divided injections is the accurate way for azoospermic model design to study cell transplantation into recipient animal because cyclophosphamide at $150 \mathrm{mg} / \mathrm{kg}$ dose is a lethal dose in mice due to their myelotoxicity.

The donor cells used in this study were antiSca- $1^{+}$ and mesenchymal stem cells. Previous reports demonstrated that bone marrow-derived mesenchymal stem cells are capable of differentiating into germ cells and Leydig cells in the testis (Nayernia et al., 2006). They used donor cells as unfractionated bone marrow cells containing hematopoietic stem cells, endothelial stem/progenitor cells, mesenchymal stem cells and multipotent adult progenitor cells. Stem cell transplantation is usually performed 4-6 weeks after treatment. The donor cells usually require 4 weeks after transplantation to attach to the basal lamina and proliferate (Yazawa et al., 2006) and an additional 4-8 weeks to produce complete seminiferous epithelium with spermatids and spermatozoa as described by (Sabbaghi et al., 2012).

On the other hand, good evidence in our studies revealed that the remaining untreated mice of group 2 (cyclophosphamide-treated group) were still azoospermic in comparison to the recovery period performed in groups 3 \& 4. Surprisingly, these observations are contrary to the finding of (Lassalle et al., 2008). There was a high proliferative and strong ability to recovery of induced azoospermia during fertility restoration and this finding become clear in histological examination and hormonal profile which showed significant differences in cyclophosphamide treated group $(\mathrm{P}<0.01)$ suggesting that cyclophosphamide causes complete atrophy in recipient mice group 2 and MSCs transplantation attempts to recover seminiferous tubules.

The synergistic effects of FSH and testosterone on the regeneration of spermatogenesis have been shown (Kula et al., 2001) together with previous observations and our results suggest that the significant changes in FSH during hormonal assessment in agreement with testosterone elevation explains closed correlation between FSH and testosterone in their role of spermatogenic recovery after and before AntiSca-1+ and MSCs transplantation.

There is a general agreement that the stem cells are contained within the population of Aund spermatogonia. C-kit-positive spermatogonia are capable of colonizing recipient testes (Barroca et al., 2008), implying that these must be differentiated spermatogonia. If this were true, then the reduced number of differentiated spermatogonia in the cycphophamide-treated mice could possibly account for the lower transplantation efficiency. However, c-kit expression begins in late stage Aal (Nakagawa et al., 2010), so the colonization ability of the c-kit positive cells could be due to Aal, which are undifferentiated spermatogonia, or possibly early stage differentiated type A cells. However the numbers of A1 spermatogonia are not reduced by the cycphophamide-treatment, so this cannot explain the lower colonizing ability of the cells from cycphophamide-treated mice.

The stem cell pool that contributes to steady state spermatogenesis is largely contained within a subpopulation of As spermatogonia, however the Apr and Aal can occasionally contribute to the stem cell pool by fragmentation (Nakagawa, et al., 2010). These chains are considered to be potential stem cells and contribute more markedly to the self-renewing stem cells during recovery from cell depletion, as occurs after treatment with a chemotherapy agent such as busulfan or after transplantation (Nakagawa et al., 2007).

Although also the present study have not determined the distribution of As, Apr, and Aal within these Aund spermatogonia, we can conclude that the percentage of stem cells should be at least as high as in the untreated testis. Since the treatment involves 7 cycphophamide doses, the presence of appreciable numbers of Apr and Aal cells, which constitute the bulk of the Aund population, at 4 days after the last treatment indicates that their progenitors, the stem cells, must have survived the first 6 injections and hence should have survived the seventh injection. The lower colonizing efficiency of cells from the cycphophamide-treated mice than from the cryptorchid mice may reflect differences within the Aund compartment. Further studies characterizing the clone size and stem and differentiation markers in the surviving Aund population from cryptorchid and cycphophamide-treated mice might further elucidate reasons for the differences in stem cell functional abilities. Another possible reason for the apparent poorer recovery of spermatogenesis from transplanted spermatogonia from cycphophamide-treated mice than from spermatogonia from cryptorchid mice, or from the cycphophamide-treated spermatogonia left in situ, is that spermatogonia from cycphophamide-treated mice have some defect in homing to the niche in the recipient tests. Defects in homing have been observed in stem spermatogonia having a low expression of $\beta 1$ - integrin (Kanatsu et al., 2008). Finally, the present finding may 
have a major impact in understanding reproductive physiology and recovery from testicular pathology and also may introduce a novel future therapy for azoospermic patients.

\section{5- References}

Abeyta, M.J.; Clark, A.T.; Rodriguez, R.T.; Bodnar, M.S.; Bodnar, M.S.; Pera, R.A. and Firpo, M.T. (2004): Unique gene expression signatures of independentlyderived human embryonic stem cell lines. Human Molecular Genetics; 3: 601-608.

Barroca, V.; Lassalle, B.; Coureuil , M.; Louis, J.P.; Le Page, F.and Testart, J. (2008); Mouse differentiating spermatogonia can generate germinal stem cells in vivo. Nat cell Biol.; 11: 190- 201.

Bukovsky, A. and Caudle, M.R. (2004): Origin of germ cells and formation of new primary follicles in adult human ovaries. Reproductive Biology and Endocrinology; 2: $20-50$

Geijsen, N.; Horoscfaak, M.; Kim, Gribnau, J.; Eggan, K. and Daley, G.Q. (2004): Derivation of embryonic germ cells and male gametes from embryonic stem cells. Nature; 427: 148- 154.

Kanatsu-Shinohara, M.; Lee, J.; Inoue, K.; Ogonuki, N.; Miki, H.; Toyokuni, S.; Ikawa, M.; Nakamura, T.; Ogura, A. and Shinohara, T. (2008): Pluripotency of a Single Spermatogonial Stem Cell in Mice, Biol Reprod, 78 (4): 681- 687.

Kolf, C.M.; Cho, E. and Tuan, R.S. (2007): Mesenchymal stromal cells. Biology of adult mesenchymal stem cells: regulation of niche, self-renewal and differentiation. Arthritis Res There; 9: 204.

Kula, K.; Walczak-Jedrzejowska, R.; SlowikowskaHilczer, J.and Oszukowska, E. (2001): Estradiol enhances the stimulatory effect of FSH on testicular maturation and contributes to precocious initiation of spermatogenesis.Mol Cell Endocrinol., 178: 89-97

Lassalle, B.; Mouthon, M.A.; Riou, L.; Barroca, V.; Coureuil, M.; Boussin, F.; Testart, J.; Allemand, I. and Fouchet, P. (2008): Bone marrow-derived stem cells do not reconstitute spermatogenesis in vivo. Stem Cells, 26: 13856.

Lue, Y.; Erkkila, K.; Liu, P.Y. ; Ma, K.; Wang, C.; Hikim, A.S. and Swerdloff, R.S. (2007): Fate of bone marrow stem cells transplanted into the testis potential implication for men with testicular failure. Am J. Pathol., 170:899-908.

Montgomery, D.C. (1997). Design and Analysis of Experiments, 4th Edition. John

Wiley \& Sons, Inc.

Nakagawa, T.; Nabeshima, Y. and Yoshida, S. (2007) function identification of the actual and potential stem cell compartments in mouse spermatogenesis. Dev cell. 12: 195- 206.

Nakagawa, T.; Sharma, M.; Nabeshima, Y.; Braun, R.E. and Yoshida, S. (2010): Functional hierarcy and reversibility within the murine spermatogenis stem cell compartment. Science; 328: 62-67.

Nayernia, K.; Lee, J.H.; Drusenheimer, N. J.; Nolte, G.; Wulf, R.; Dressel, J.; Gromoll and Engel,W. (2006): Derivation of male germ cells from bone marrow stem cells. Lab Invest., 86: 654-663.

Nayernia, K.; Li, M.; Jaroszynski, L.; Khusainov, R.; Wulf, G.and Schwandt, I. (2004): Stem cell based therapeutical approach of male infertility by teratocarcinoma derived germ cells. Hum Mol Genet; 13: 1451-1460.

Nayernia, K.; Nolte, J.; Michelmann, H.W.; Lee, J.H.; Rathsack,K.and Drusenheimer, N. (2006): In vitrodifferentiated embryonic stem cells give rise to male gametes that can generate offspring mice. Dev Cell; 11: 125-132.

Ogawa, T.; Dobrinski, I.and Brinster, R.L. (1999): Recipient preparation is critical for spermatogonial transplantation in the rat. Tissue Cell.; 31(5):461- 472.

Phinney, D.G. and Prockop, D.J. (2007): Concise review: mesenchymal stem / multipotent stromal cells: the state of transdifferentiation and modes of tissue repaircurrent views. Stem Cells; 25: 2896-2902.

Sabbaghi, M.A., Ahmad Reza Bahrami, Behzad Frizzed, Seyed Mehdi Kalantar, Maryam M. Matin, Mahmood Kalantari, A.A. and Saeinasab, M. (2012): Trial evaluation of bone marrow derived mesenchymal stem cells (MSCs) transplantation in revival of spermatogenesis in testicular torsion. Middle East Fertility Society Journal, 17: 243-249.

Satija, N.K.; Gurudutta, G.U.; Sharma, S.; Afrin, F.; Gupta, P. and Verma, Y.K, (2007): Mesenchymal stem cells: molecular targets for tissue engineering. Stem Cells Dev; 16: 7-23.

Stojkovic, M.; Lako, M.; Strachan, T. and Murdoch, A. (2004): Derivation, growth and applications of human embryonic stem cells. Reproduction; 128: 259-267.

Toyooka, Y.; Tsunekawa, N.; Akasu, R. and Noce, T. (2003): Embryonic stem cells can form germ cells in vitro. Proc Natl Acad Sci USA; 100 : 11457- 11462.

Yazawa, T.; Mizutani, T.; Yamada, K.; Kawata, H.; Sekiguchi, T.; Yoshino, M.; Kajitani, T.; Shou, Z.; Umezawa, A. and Miyamoto, K. (2006): Differentiation of adult stem cells derived from bone marrow stroma into Leydig or adrenocortical cells. Endocrinology, 147: 4104411. 